\title{
有酸素的作業能の一因子としての肺拡散容量
}

\author{
山 地 啓 司* 猪 飼 道 夫** \\ （昭和46年10月 25 日受付）
}

\section{Pulmonary Diffusing Capacity as a Factor of Aerobic Work Capacity}

Keiji Yamaji and Michio Ikai

(School of Education, University of Tokyo)

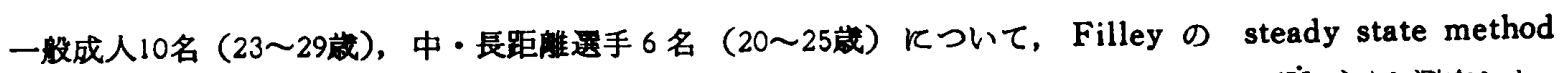

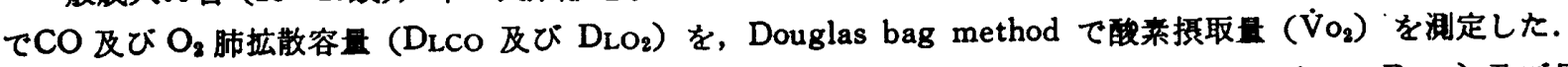

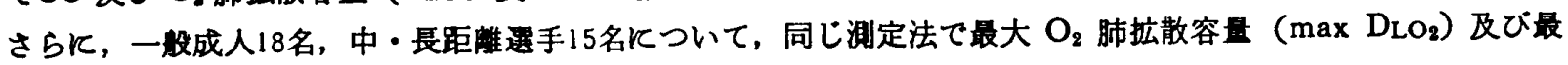
大酸素摄取量 $\left(\max \dot{\mathrm{V}} \mathrm{O}_{2}\right)$ を湘定した.

その結果，両グループとも酸素摄取量 $\left(\dot{\mathrm{V}} \mathrm{O}_{2}\right)$ の增加とともなって CO 及び $\mathrm{O}_{2}$ 肺拉散容量(DLCo 及び D LO2）が比例して增加することを認めた。 また，中・長距離選手は一般成人よりも同一量の酸亲を摄取する時，

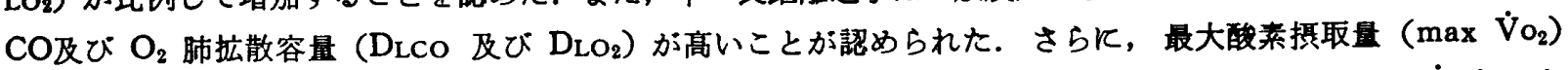
と最大 $\mathrm{O}_{2}$ 肺拡散容量 ( $\left.\max \mathrm{DLO}_{2}\right)$ との間飞は相関係数が $\mathrm{r}=0.817$ となり, 最大酸素摄取量 $\left(\max \dot{\mathrm{V}} \mathrm{O}_{2}\right)$ が大 きい者は最大 $\mathrm{O}_{2}$ 肺拡散容量も大きいことが明らかとなった。

Although it is a well known fact that the pulmonary diffusing capacity is a key factor of aerobic work capacity, the available data are not sufficient for further discussion on basic training of endurance. The authors had conducted a series of measurement of pulmonary diffusing capacity for $\mathrm{O}_{2}$ together with that of oxygen intake during the work. The work was given to the subjects on a bicycle ergometer with the load of progressively increasing up to nearly the maximal level. The subjects were chosen from ordinary healthy males and trained middle and long distance runners. To determine the pulmonary diffusing capacity, Filley's steady state method was used. And for oxygen intake, Douglas bag method was adopted using Scholander's apparatus. The results were as follows:

(1) The pulmonary diffusing capacity for oxygen at rest was observed to be 22.3 and 32.4 $\mathrm{ml} / \mathrm{min} / \mathrm{mmHg}$ in ordinary and trained subjects respectively.

(2) The pulmonary diffusing capacity for $\mathrm{O}_{2}$ was increased together with the oxygen intake during the work. The regression lines were presented as follows:

$\hat{\mathrm{Y}}=8.83 \mathrm{X}+22.07 \cdots \cdots \cdots \cdots$ for ordinary subjects

$\hat{\mathrm{Y}}=8.32 \mathrm{X}+32.36 \cdots \cdots \cdots \cdots$. for trained subjects

where $\hat{\mathrm{Y}}$ showed diffusing capacity and $\mathrm{X}$ showed oxygen intake.

(3) A close relationship was found between the maximum oxygen intake and the maximum diffusing capacity for oxygen with a correlation coefficient of $r=0.817$.

(4) Based on these results, it is supposed that the pulmonary diffusing capacity will be increased during the work as one of the contributing factors of aerobic work capacity.

(Yamaji, K., and Ikai, M., : Pulmonary Diffusing Capacity as a Factor of Aerobic Work Capacity, Research Journal of Physical Education, Vol. 17, No.1, May, 1972, pp. 7 16)

* 東京大学 **1972年1月3日逝去 


\section{楮敦}

全身持久性を規定する因子について，これまで 多くの研究者によって呼吸・循環機能の面から追 求されてきた。Andersen (1961) ${ }^{1)}$ はヒトの作業 能 (Physical working capacity) を示す適切な指 標は最大酸菜摄取量 (Maximal oxygen intake : $\max \dot{\mathrm{V}_{2}}$ ) であると述へている，最大酸素捸取量 ( $\max \dot{V} \mathrm{O}_{2}$ ) は呼吸循環機能を総括的にみたもの である、これに関与する因子として，Holmgren $(1967)^{12)}$ は(1)肺換気量 (Ventilation: $\left.\dot{\mathrm{V}}_{\mathrm{E}}\right)(2) \mathrm{O}_{2}$ 肺扗散容量 (Oxygen diffusing capacity: $\mathrm{D}_{\mathrm{LO}_{2}}$ ) (3) 心拍出量 (Cardiac output： $\dot{\text { Q) }}$ (4) 組織拡散容量 (Tissue diffusing capacity: $\mathrm{D}_{\mathrm{T}}$ ) などを挙げてい る.これらの因子の中でも，呼吸系之循環系の二 つの機能が関与している $\mathrm{O}_{2}$ 肺拡散容量 $\left(\mathrm{D}_{\mathrm{LO}}\right)$ が重要な因子と考えられている。

$\mathrm{O}_{2}$ 肺拡散容量 $\left(\mathrm{D}_{\mathrm{LO}_{2}}\right)$ は Bohr $(1909)^{5)}$ Kよ って公式化され，Krogh (1915) ${ }^{18)}$ によって初め て実際に測定された。 その後, Forster $(1954)^{8)}$ が一回呼吸法 (Single breath method), Filley (1 954) ${ }^{7)}$ が定常法 (Steady state method) を発表 するに至って，測定が容易となった．Holmgren

$\left.\left(1964,{ }^{11}\right) 1965\right)^{10)}$ は定常法で CO 肺拡散容量 （D LCO）を測定し，心拍数は $120 / \mathrm{min}(40 \%$ of $\max \dot{V}_{o_{2}}$ ) まで直線的に上昇するが，その後，酸 素摄取量 $\left(\dot{\mathrm{V}}_{2}\right)$ の増加にもかかわらず一定であ ることを報告している，また，Magel (1969) ${ }^{20) ，}$ Johnson (1965) ${ }^{18)}$ は CO 肺払散容量 ( $\mathrm{D}_{\text {LCO }}$ ) が最大酸素摄取量 $\left(\max \dot{V} \mathrm{O}_{2}\right)$ にさきだち定常状 態 (steady state) になることを認めている. しか ᄂ, Linderholm (1959) ${ }^{19)}$, Pirnay (1969) ${ }^{25)}$, Shepard(1958) 29) らは定常法で, Bannister (19 $60)^{3)}$, Cotes $(1960)^{6)}$, Newman $(1962)^{23)}$ らは一 回呼吸法で酸素拱取量 $\left(\dot{\mathrm{V}}_{2}\right)$ と $\mathrm{CO}$ 肺拡散容量 （DLCO）が直線関係であることを明らかにしてい る.

このよ5に，酸素摄取量 $\left(\mathrm{V}_{2}\right)$ の因子である $\mathrm{CO}$ 肺抎散容量 (DLCO) は酸素摄取量 $\left(\dot{V}_{\mathrm{O}_{2}}\right)$ の 增加とともに增加するが，酸素捸取量 $\left(\dot{\mathrm{V}}_{\mathrm{O}_{2}}\right)$ が一 定以上になると，それ以上增加しないとい5 報告 と，どこまでも酸素捸取量 $\left(\dot{\mathrm{V}}_{2}\right)$ と一定の関係を
保ちつつ增加するという報告に区別されるささら に，最大酸素摂取量 $\left(\max \dot{\mathrm{V}} \mathrm{O}_{2}\right)$ とその時の $\mathrm{CO}$ 肺拡散容量 (D LCO) の関係についての報告は諸外 国ではほとんど見あたらず，わずか我国において 草野 ${ }^{17} の$ 例をみるだけである。

本研究は日本人の一般成人と中・長距蜼選手に ついて, 酸素摄取量 $\left(\dot{\mathrm{V}}_{2}\right)$ と $\mathrm{O}_{2}$ 肺払散容量 (D LO2）の関係をみたものである. また，両グループ について, $\mathrm{O}_{2}$ 肺拡散容量 $\left(\mathrm{DLO}_{2}\right)$ に関与する肺 胞 $\mathrm{O}_{2}$ 分俚 $\left(\mathrm{P}_{\mathrm{AO}}\right)$, 肺胞毛細管血の $\mathrm{O}_{2}$ 分圧 $\left(\mathrm{P}^{2} \mathrm{C}_{2}\right)$ が酸案摄取量 $\left(\mathrm{V}_{2}\right)$ の增加とともにどの よ5に関係していくか，さらに一般成人，中長距 嚄選手の最大酸素提取量 $\left(\max \dot{\mathrm{V}} \mathrm{o}_{2}\right)$ と最大肺拡散 容量 ( $\left.\max \mathrm{D}_{\mathrm{LO}}\right)$ の関係を明らかにすることによ っ がどのよ5に関与しているかを探究するものとし た。

\section{方 法}

最大下作業における被検者は健康な日本人の一 般成人男子 10 名 (23〜29歳) とメキショ・オリン ピック選手を含を日本人の中長距離選手 6 名 (20 〜25歳)である. 両グループの身体的特性は表 1 に示してある．最大作業における被検者は一般成 人男子18名 (19～29歳), 中・長距離 選手 15 名 （18～25歳）である．運動負荷はモナーク社製自 転車エルゴメーターを用いた。最大下作業は各々 被検者について，一定負荷法でまず，0.5kp の真 荷で 5 分間行い，日を改め次に $1.0 \mathrm{kp}$ の負荷で 5 分間行なった。このように負荷を実験ごとに $0.5 \mathrm{k}$ $\mathrm{p}$ ずつ增加させ， 5 分間続けられなくなる負荷ま で增加させた５分間続けられる最大の作業を最 大下作業の最大と呼んだ。さらに，最大酸素摂取 量 $\left(\max \dot{V}_{o_{2}}\right)$ を求めるために, 改めて最大作業 を行なった，それは 4〜 7 分で all-out になるよ 5 に最初の負荷を定め，1 分ごとの漸增負荷法で 行なった。なおすへでの自転車の作業における 回転数はメトロノームに合わせ $60 \mathrm{rpm}$ とした。 また，作業にさきたち， $2.0 \mathrm{kp} て ゙ 3$ 分間ウォーミ ング・アップを行ない, 3 分間の休息後作業を行 なった。

吸気としてあらかじめ,ダグラスバッグの中へ 
表 1 被検者の身体的特性

\begin{tabular}{c|c|c|c|c|c}
\hline & Subj. & Age & $\begin{array}{c}\text { Height } \\
(\mathrm{cm})\end{array}$ & $\begin{array}{c}\text { Weight } \\
(\mathrm{kg})\end{array}$ & $\begin{array}{c}\text { Surface area } \\
\left(\mathrm{m}^{2}\right)\end{array}$ \\
\hline \multirow{6}{*}{ Non-athletes } & K.W. & 24 & 169.1 & 59.0 & 1.67 \\
& H. T. & 27 & 171.7 & 72.0 & 1.86 \\
& K. K. & 23 & 158.3 & 56.0 & 1.60 \\
& T. F. & 28 & 168.2 & 66.0 & 1.77 \\
& K. I. & 27 & 168.3 & 57.0 & 1.65 \\
& S. T. & 28 & 163.7 & 66.0 & 1.74 \\
& K. U. & 25 & 172.0 & 62.0 & 1.75 \\
& Y. S. & 26 & 163.5 & 67.0 & 1.74 \\
& K. N. & 24 & 170.2 & 64.0 & 1.74 \\
& T.Y. & 29 & 160.0 & 59.5 & 1.64 \\
\hline & mean & 26.1 & 166.5 & 62.85 & 1.68 \\
& S. D. & 3.14 & 11.56 & 15.99 & 0.38 \\
\hline \multirow{6}{*}{ Athletes } & J. N. & 25 & 169.5 & 58.1 & 1.67 \\
& J.T. & 23. & 179.0 & 65.4 & 1.84 \\
& A.M. & 20 & 167.2 & 58.0 & 1.68 \\
& M. A. & 22 & 172.0 & 62.0 & 1.75 \\
& S. S. & 21 & 164.3 & 58.5 & 1.65 \\
& M. L. & 21 & 172.9 & 61.2 & 1.74 \\
\hline & mean & 22 & 170.8 & 60.53 & 1.72 \\
& S. D. & 1.79 & 5.72 & 3.01 & 0.01 \\
\hline
\end{tabular}

外気と $0.05 \%$ の一酸化炭素 (CO) の混合ガスを 作り, 最大下作業では採気 15秒前からマウスピー スを通し吸わせ，運動開始後 4 分目と 5 分目の 1 分間ダグラスハッグ法で採気を行なった，最大作 業では all-out 約 1 分15秒前から CO 混合ガスの 吸気を開始し，15秒後から all-out まで採気を行 なった。吸気および呼気の $\mathrm{CO}$ 濃度は Beckman $\mathrm{CO}$ Analyzer を用い, $\mathrm{CO}_{2}, \mathrm{O}_{2}$ 濃度は Scholander ガス分析器で分析を行なった。 さらに，ガス メーターで換気量を測り，酸素摄取量 $\left(\mathrm{V}_{2}\right)$ 和よ び一酸化炭素摄取量（ $\dot{V}_{\mathrm{CO}}$ ) を算出した。肺胞 C $\mathrm{O}_{2}$ 分圧 $\left(\mathrm{P}_{\mathrm{ACO}_{2}}\right)$ は LB-1 Co $\mathrm{Co}_{2}$ Analyzer を用い, end-tidal 法で求め, Bohr の呼吸死腔式から肺胞 $\mathrm{CO}$ 分压 $\left(\mathrm{P}_{\mathrm{ACO}}\right)$ を算出した。平均肺毛細管血 $\mathrm{C}$ $\mathrm{O}$ 分生 ( $\mathrm{P} \ddot{\mathrm{C} C O})$ を零とみなし, 次の式に代入し て, 肺拡散容量 (DLCO) を求めた.

$\mathrm{D}_{\mathrm{LCO}}=\dot{\mathrm{V}}_{\mathrm{CO}} /\left(\mathrm{P}_{\mathrm{ACO}}-\mathrm{PC} \mathrm{CO}\right)$

肺胞 $\mathrm{O}_{2}$ 分圧 $\left(\mathrm{P}_{\mathrm{AO}_{2}}\right)$ は呼気ガスの酸素濃度と 気压の積から求められた。一酸化炭素 (CO) と酸 素 $\left(\mathrm{O}_{2}\right)$ の溶解度と分子量の比によって酸素肺拡散
容量 $\left(\mathrm{D}_{\mathrm{LO}}\right)$ を算出した。肺胞毛細管血 $\mathrm{O}_{2}$ 分圧 $\left(\mathrm{PCO}_{2}\right)$ はすでに算出された酸素摄取量 $\left(\dot{\mathrm{VO}}_{2}\right), \mathrm{O}_{2}$ 肺拡散容量 $\left(\mathrm{D}_{\mathrm{LO}}\right)$, 肺胞 $\mathrm{O}_{2}$ 分王 $\left(\mathrm{P}_{\mathrm{AO}_{2}}\right)$ をBohr の公式に代入して求めた。

なお，安静値は15分間椅子に座った後，5分間 採気し, $\mathrm{CO}$ 肺抬散容量 (DLCO), 酸素摄取量 ( $\dot{V}$ ○文を測定した。

\section{䊅 果}

（1）最大下作業について

健康な一般成人男子 10 名と中・長距離選手 6 名 について, 最大下作業時の酸素摄取量 $\left(\mathrm{V}_{0} \mathrm{O}_{2}\right)$ とCO および $\mathrm{O}_{2}$ 肺拡散容量 (DLCO 及び $\left.\mathrm{DLO}_{2}\right)$ の関係 を調べた（困 1，図 2)，安静時の CO 肺拡散容 量(DLCO) は一般成人が $18.4 \mathrm{ml} / \mathrm{min} / \mathrm{mmHg}$ (D $\mathrm{LO}_{2}: 22.3$ ), 中・長距離選手 $26.7 \mathrm{ml} / \mathrm{min} / \mathrm{mmHg}$ (D LO2 $: 32.4 ）$ となり，両グループの間に $5 \%$ 水準で 有意差を認めないが，最大下作業に打ける最大作 業時の CO 肺拡散容量 ( $\mathrm{D}_{\mathrm{LCO}}$ ) では一般成人33. $9 \mathrm{ml} / \mathrm{min} / \mathrm{mmHg}\left(\mathrm{DLO}_{2}: 41.8\right)$, 中・長距離選手 


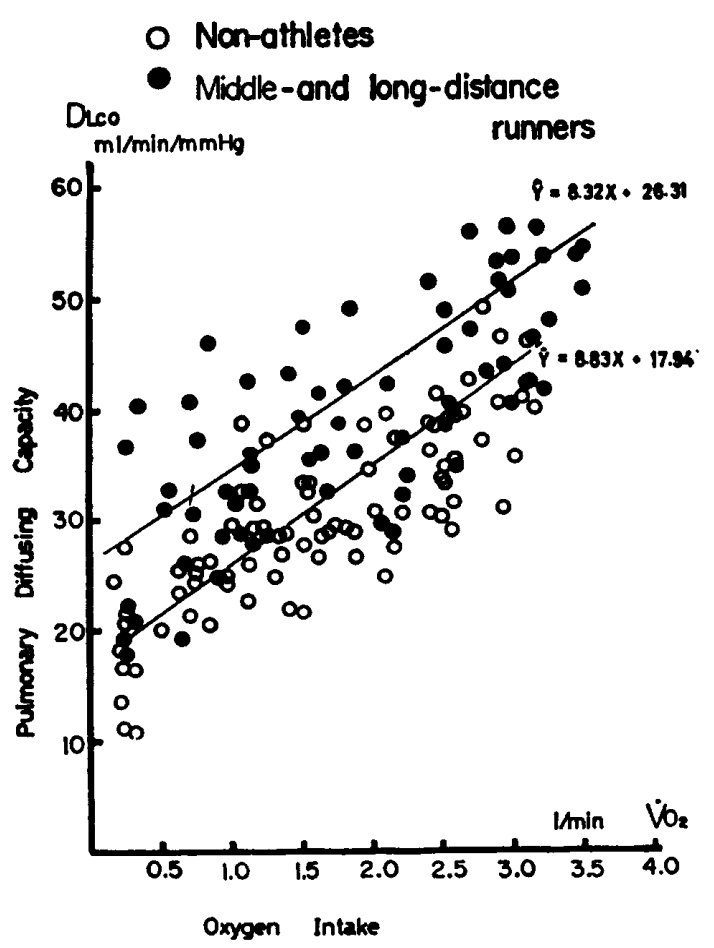

因 1 一般成人と中・長距離選手の酸菜摄取量 $\left(\dot{\mathrm{V}}_{\mathrm{O}_{2}}\right)$ と CO 肺拡散容旦 (DLCO) との夙係

$48.5 \mathrm{ml} / \mathrm{min} / \mathrm{mmHg}\left(\mathrm{D}_{\mathrm{LO}}: 59.7\right)$ となり, 両ク ループの間に $1 \%$ 水準で有意差を認めた。両グ ループの CO および $\mathrm{O}_{2}$ 肺払散容量 (D Lco 及び $\left.\mathrm{D}_{\mathrm{LO} 2}\right)$ は酸素摄取量 $\left(\dot{\mathrm{V}}_{2}\right)$ の增加につれ，比例 して増加することを認めた．その回帰直線は一般 成人では，次のよ5になる。

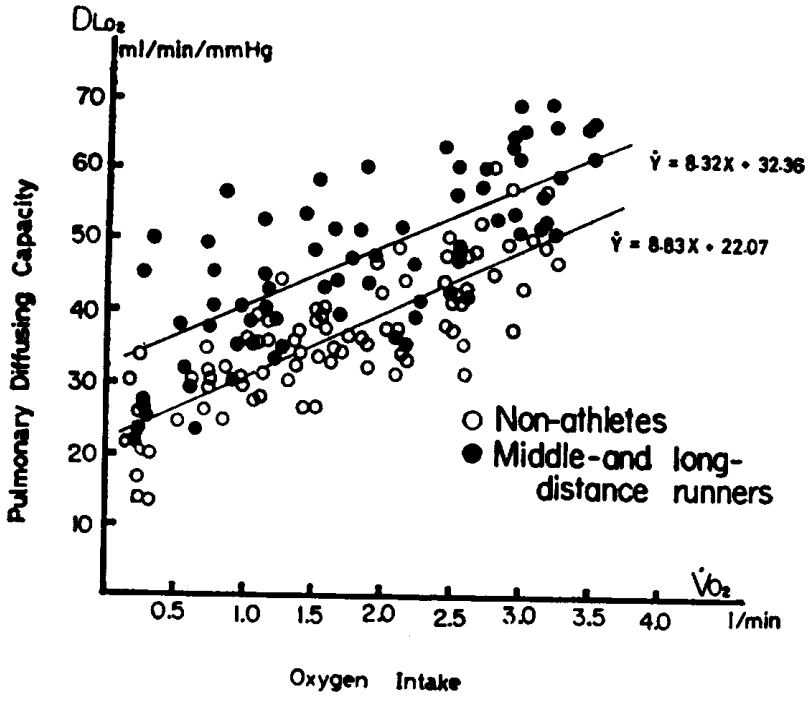

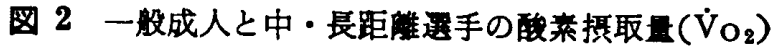
と $\mathrm{O}_{2}$ 肺拡散容量 $\left(\mathrm{DLO}_{2}\right)$ との関係

$$
\hat{\mathrm{Y}}=8.83 \mathrm{X}+17.94\left(\mathrm{D}_{\mathrm{LO} 2}: \hat{\mathrm{Y}}=8.83 \mathrm{X}+22.07\right) \text {, }
$$
また，中・長距離選手では

$$
\hat{\mathrm{Y}}=8.32 \mathrm{X}+26.31\left(\mathrm{D}_{\mathrm{LO}_{2}}: \hat{\mathrm{Y}}=8.32 \mathrm{X}+32.36\right)
$$

（四1，罒2）であった。そして，両クループの 回帰直線の間には $1 \%$ 水準で有意差を認めた。 そ の結果, 安静時から最大作業時まで同一量の酸素 を摄取するとき，中・長距離選手は一般成人より も $\mathrm{CO}$ および $\mathrm{O}_{2}$ 肺拡散容量 ( $\mathrm{D}_{\mathrm{LCO}}$ 及び $\mathrm{D}_{\mathrm{LO}}$ ) が大きいことが明らかとなった。

本測定では CO 肺拡散容量(DLCO) で測定され たが，実際には酸素が肺胞膜より血液中に抎散す

\begin{tabular}{|c|c|c|c|c|c|c|c|c|c|}
\hline \multirow[b]{2}{*}{ Subj } & \multirow[t]{2}{*}{ Rest } & \multicolumn{8}{|c|}{ Work Rate (kpm/min) } \\
\hline & & 180 & 360 & 540 & 720 & 900 & 1080 & 1260 & 1440 \\
\hline K. W. & 20.1 & 30.9 & 38.5 & 44.8 & 33. 0 & 47.1 & 42.5 & 47.2 & \\
\hline H. T. & 13.5 & 31.7 & 35.4 & 30.3 & 40.9 & 30.7 & 41.4 & & \\
\hline $\mathrm{K} \cdot \mathrm{K}$. & 16.7 & 25.0 & 35.9 & 33. 9 & 32.6 & 37.9 & 48.4 & 39.8 & \\
\hline T. F. & 33.9 & 26.1 & 29.5 & 35.1 & 35.0 & 37.8 & 51.0 & 52.9 & 53.7 \\
\hline K. I. & 22.3 & 29.3 & 36.0 & 34.9 & 47.8 & 46.2 & 46.2 & 48.1 & 48.0 \\
\hline S. T. & 26.7 & 35.1 & 28.1 & 27.0 & 34.6 & 33.4 & 43. 4 & & \\
\hline K. U. & 13.1 & 30.8 & 30.6 & 32.9 & 40.9 & 35.5 & 34.4 & 35.5 & 38.0 \\
\hline Y. S. & 20.5 & 39.9 & 33.8 & 37.0 & 38.9 & $42 \cdot 7$ & 45.6 & 43.8 & 49. 4 \\
\hline K. N. & 26.1 & 29.7 & 31.7 & 39.6 & 37.2 & 49.0 & 47.9 & 50.0 & 57.4 \\
\hline T. Y. & 30.2 & 24.6 & 32.2 & 28.0 & 26.8 & 36.4 & & & \\
\hline mean & 22.31 & 30.31 & 33.17 & 34.35 & 36.77 & 39.67 & 44.52 & 45. 32 & 49. 30 \\
\hline S. D. & 7.74 & 7.29 & 6.53 & 7.59 & 7.66 & 6.13 & 5.51 & 10. 28 & 13.75 \\
\hline
\end{tabular}

表 2 一般成人の作業强度と肺搪散容至 $\left(\mathrm{DLO}_{2}: \mathrm{ml} / \mathrm{min} / \mathrm{mmHg}\right)$ 


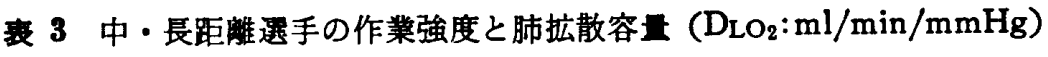

\begin{tabular}{c|r|r|r|r|r|r|r|r|r|r}
\hline & \multicolumn{7}{|c|}{ Rest } & \multicolumn{8}{|c}{ Work Rate (kpm/min) } \\
\cline { 2 - 10 } Subj. & & \multicolumn{1}{|c|}{180} & \multicolumn{1}{|c}{360} & 540 & \multicolumn{1}{c}{720} & 900 & 1080 & 1260 & 1440 & 1620 \\
\hline J. N. & 22.0 & 23.8 & 30.5 & 34.0 & 35.1 & 44.4 & 46.0 & 43.0 & 52.3 & \\
J. T. & 50.3 & 38.0 & 40.4 & 35.2 & 43.8 & 47.7 & 41.9 & 47.3 & 51.4 & 59.5 \\
A. M. & 27.3 & 38.2 & 45.5 & 43.3 & 51.5 & 44.3 & 51.8 & 63.6 & 57.9 & 66.2 \\
M. A. & 25.5 & 40.3 & 56.7 & 45.0 & 58.4 & 60.3 & 51.9 & 60.1 & 60.4 & 62.0 \\
S. S. & 45.5 & 32.1 & 35.1 & 40.0 & 53.5 & 40.0 & 39.5 & 56.4 & 53.2 & 52.0 \\
M. L. & 23.9 & 49.8 & 38.9 & 52.4 & 48.7 & 36.3 & 35.4 & 49.8 & 62.3 & 66.4 \\
\hline \hline mean & 32.41 & 37.03 & 41.18 & 41.65 & 48.50 & 45.50 & 44.41 & 53.36 & 56.41 & 61.22 \\
S. D. & 12.80 & 8.71 & 8.71 & 7.63 & 9.06 & 9.75 & 9.27 & 10.28 & 5.62 & 7.15 \\
\hline
\end{tabular}

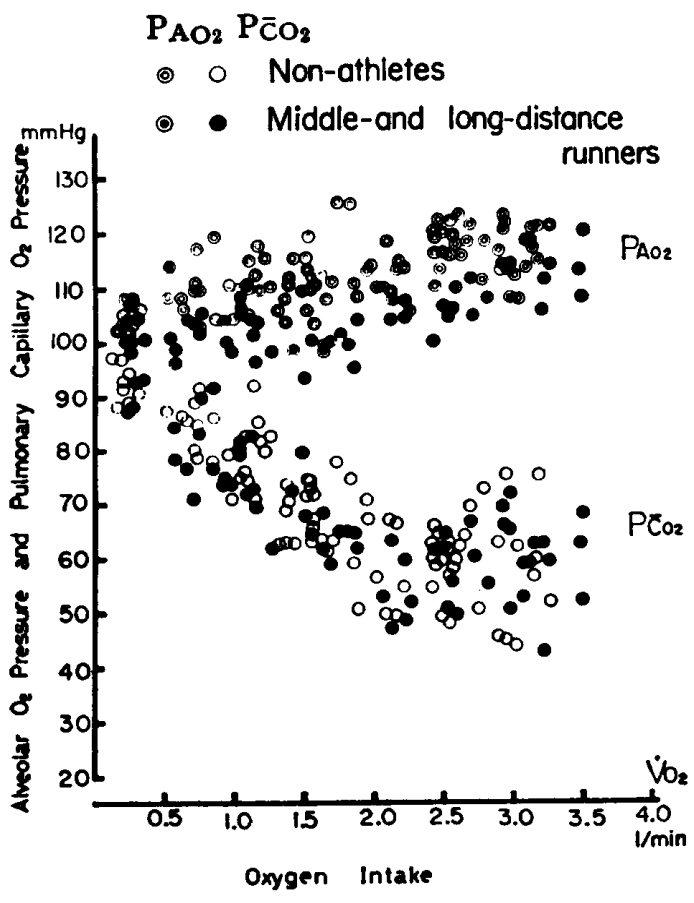

因 3 一般成人と中・長距崔選手の酸菜摄取量 $\left(\mathrm{V}_{2}\right)$ と肺胞 $\mathrm{O}_{2}$ 分王 $\left(\mathrm{PAO}_{2}\right)$, 平均肺毛 細管血 $\mathrm{O}_{2}$ 分代 $\left(\mathrm{P}_{\overline{\mathrm{CO}}}\right)$ との関係

る.そこで，CO 肺执散容量(DLCO) を 1.23 倍す ることによって $\mathrm{O}_{2}$ 肺拡散容量 $\left(\mathrm{DLO}_{2}\right)$ の值に换 算した. 因 2 は酸素提取量 $\left(\mathrm{VO}_{2}\right)$ と $\mathrm{O}_{2}$ 肺拡散容

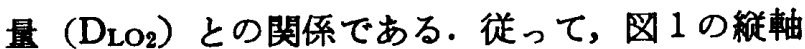
の DLCo を1.23倍したものと同じである.また， 作業強度と $\mathrm{O}_{2}$ 肺拡散容量 $\left(\mathrm{D}_{\mathrm{LO}}\right)$ との関係を表 2 ，表 3 に示した。

酸素摄取量 $\left(\dot{\mathrm{V}}_{2}\right)$ と肺胞 $\mathrm{O}_{2}$ 分代 $\left(\mathrm{P}_{\mathrm{AO}}\right)$, 平 均肺胞毛細管血 $\mathrm{O}_{2}$ 分圧 $\left(\mathrm{P} \mathrm{CO}_{2}\right)$ との関係を示し たのが困 3 である. 安静時の肺胞 $\mathrm{O}_{2}$ 分圧 $\left(\mathrm{P}_{\mathrm{AO}}\right)$

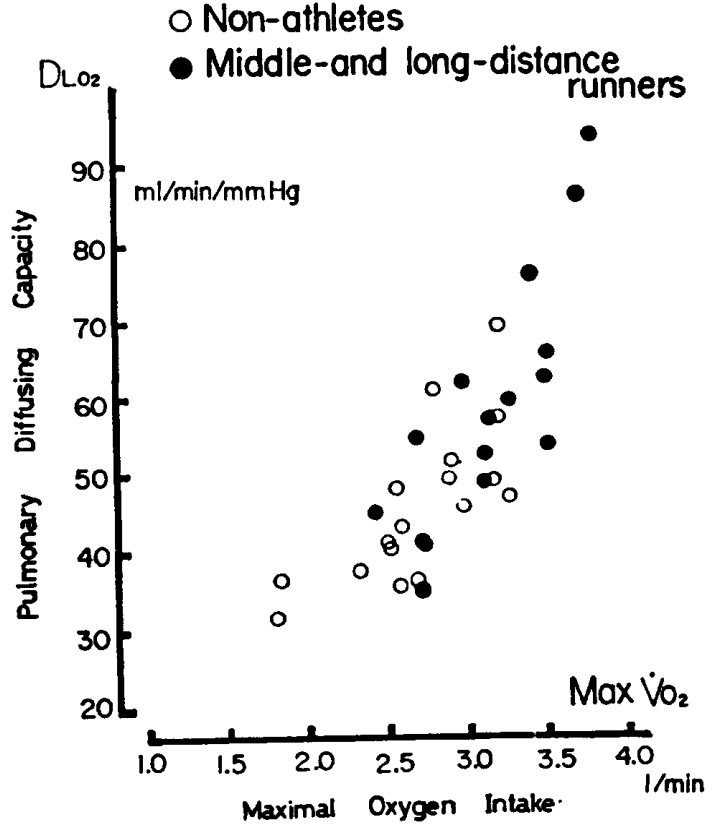

図 4 一般成人 (18名)，中・長距離選手 (15名) の計 33 名の最大酸菜摄取量 $\left(\max \dot{\mathrm{V}}_{2}\right)$ と最 大 $\mathrm{O}_{2}$ 肺拡散容量 $\left(\max \mathrm{DLO}_{2}\right)$ との関係

は一般成人 $104.4 \mathrm{mmHg}$, 中・長距離選手 $103.1 \mathrm{~mm}$ $\mathrm{Hg}$ であった。一般成人では酸素摄取量 $\left(\mathrm{V}_{\mathrm{O}}\right)$ が 䄪 $2.01 / \mathrm{min}$ まで, 肺胞の $\mathrm{O}_{2}$ 分王 $\left(\mathrm{P}_{\mathrm{AO}}\right)$ は約 $110 \mathrm{mmHg}$ であり, 以後, 過呼吸になるに従って 肺胞の $\mathrm{O}_{2}$ 分圧 $\left(\mathrm{P}_{\mathrm{AO}_{2}}\right)$ は高くなり, 最高 120.2 $\mathrm{mmHg}$ まで增加した。一方, 中・長距離選手で は約 $2.51 / \mathrm{min}$ まで安静時よりわずかに低下し， 以後, 酸素摄取量 $\left(\dot{\mathrm{V}_{2}}\right)$ の增加ととすに上昇し, 酸菜摄取量 $\left(\dot{\mathrm{V}}_{\mathrm{O}_{2}}\right)$ が $3.51 / \mathrm{min}$ の時 $114.0 \mathrm{mmHg}$ まで高くなつた。 
表 4 一般成人, 中・長距離選手の最大酸亲攝取 量( $\left.\max \dot{\mathrm{V}}_{\mathrm{O}_{2}}: 1 / \mathrm{min}\right)$ と最大酸素肺拡散容量 ( $\max \mathrm{D}_{\mathrm{LO}_{2}}: \mathrm{ml} / \mathrm{min} / \mathrm{mmHg}$ )

\begin{tabular}{|c|c|c|c|}
\hline & Subj. & $\underset{1 / \mathrm{min}}{\max } \dot{\mathrm{Vo}}_{2}$ & $\begin{array}{c}\max \mathrm{DLO}_{2} \\
\mathrm{ml} / \mathrm{min} \\
/ \mathrm{mmHg}\end{array}$ \\
\hline \multirow{20}{*}{ 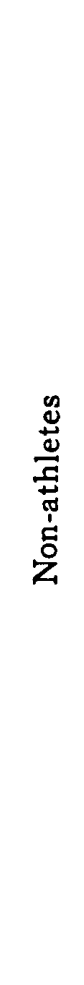 } & T. H. & 2.71 & 41.4 \\
\hline & $\mathrm{K} . \mathrm{U}$. & 3. 26 & 47.0 \\
\hline & T. F. & 3. 19 & 69.5 \\
\hline & S. S. & 2.78 & 61.0 \\
\hline & K. N. & 3.19 & 57.2 \\
\hline & T. S. & 2.55 & 48.0 \\
\hline & Y.M. & 1.80 & 31.5 \\
\hline & T. Y. & 1.83 & 36.4 \\
\hline & K. Y. & 2. 32 & 37.6 \\
\hline & T. A. & 2.57 & 35.5 \\
\hline & K. I. & 2.68 & 36.5 \\
\hline & S. S. & 2.51 & 40.5 \\
\hline & H. T. & 2.50 & 41.5 \\
\hline & S. T. & 2.58 & 43.6 \\
\hline & B. N. & 2.97 & 45.8 \\
\hline & K. K. & 2.88 & 49.5 \\
\hline & K. W. & 2.89 & 51.5 \\
\hline & Y. S. & 3.16 & 49.0 \\
\hline & mean & 2.69 & 45.7 \\
\hline & S. D. & 0.42 & 9.73 \\
\hline \multirow{6}{*}{$\begin{array}{l}\stackrel{\infty}{2} \\
\stackrel{\Xi}{\Xi} \\
\stackrel{\Xi}{\Xi}\end{array}$} & A. $\mathrm{K}$. & 2. 42 & 45.0 \\
\hline & $\mathrm{K} \cdot \mathrm{H}$. & 2.70 & 35.0 \\
\hline & H. Y. & 2.73 & 40.8 \\
\hline & T. Y. & 2.67 & 54.5 \\
\hline & J. N. & 3. 10 & 49.0 \\
\hline & I. T. & 3. 10 & 52.5 \\
\hline \multirow{9}{*}{ 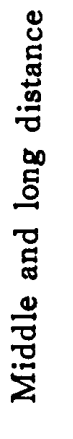 } & M. A. & 2. 96 & 62.0 \\
\hline & S. S. & 3.13 & 57.0 \\
\hline & J. T. & 3.26 & 59.5 \\
\hline & Y. K. & 3.50 & 53.8 \\
\hline & Y.A. & 3. 48 & 62.5 \\
\hline & A. M. & 3.50 & 65.8 \\
\hline & Y. T. & 3. 40 & 76.0 \\
\hline & Y. I. & 3.70 & 86.0 \\
\hline & S. S. & 3.79 & 93.6 \\
\hline & mean & 3.16 & 59.5 \\
\hline & S. D. & 0.41 & 15,98 \\
\hline
\end{tabular}

また，平均肺胞毛細管血 $\mathrm{O}_{2}$ 分圧 $\left(\mathrm{PCO}_{2}\right)$ は一般 成人，中・長距離選手の区別なく約 $2.0 \sim 2.51 / \mathrm{min}$ まで直線的に低下し，約 $60 \mathrm{mmHg}$ まで低下した。 その後, 酸素摂取量 $\left(\mathrm{V}_{\mathrm{O}_{2}}\right)$ の增加にもかかわらず
分散は大きくなるがほほ $60 \mathrm{mmHg}$ を保っている ことが認められた。

（2）最大作業について

一般成人男子 18 名 (19 29歳)，中・長距離選 手15名（18～25歳）について，最大酸素攝取量 $\left(\max \dot{V}_{\mathrm{O}_{2}}\right)$ と最大 $\mathrm{O}_{2}$ 肺拡散容量 $\left(\max \mathrm{D}_{\mathrm{LO}_{2}}\right)$ との関係を調へた（表 4). その結果，相関係数 $\mathrm{r}=0.817(\mathrm{p}<0.001)$ で有意な 相関があることが明 らかとなった。

一般成人, 中・長距離選手の最大酸素摂 取量 $\left(\max \dot{\mathrm{V}}_{2}\right)$ の平均值はそれぞれ2.69，3.16l/min となり, 最大 $\mathrm{O}_{2}$ 肺拡散容量 $\left(\max \mathrm{D}_{\mathrm{LO}_{2}}\right)$ の平均 值はそれぞれ 45.7,59.5 $\mathrm{ml} / \mathrm{min} / \mathrm{mmHg}$ であっ た.また，全体を通じて最大 $\mathrm{O}_{2}$ 肺拡散容量 $(\max$ $\mathrm{D}_{\mathrm{LO}_{2}}$ )の最高值は長距離選手 S. S. の $93.6 \mathrm{ml} / \mathrm{min}$ $/ \mathrm{mmHg}$ であり, 最大酸素摂取量 $\left(\max \dot{\mathrm{V}} \mathrm{o}_{2}\right)$ は $3.79 l / \mathrm{min}$ であった.

\section{考察}

CO 肺拡散容量 ( $\left.D_{\text {LCO }}\right)$ の測定にはsingle breath method (一回呼吸法) と steady state method

（定常法）の二種類が主に使用されている. 兩者 の根本的な差異は前者が 一定時間の呼吸停止状態 での拡散值であるのに対して，後者は自然な呼吸 状態のものである. Anderson (1968) ${ }^{2)}$ は single breath method と steady state method との差異 の原因が（a）一回呼吸量と呼吸数之の割合 (b) 毛 細管血中の $\mathrm{CO}$ を零とみなした場合と不適当な補 正にあると報告している. Single breath method は呼吸停止前に肺容積 (TLC) に所定の CO 混合 ガスを満すことによって，肺胞を拡張し，それに よって肺の有効执散面積を増大する特長をむって いる.しかし, single breath method では激しい 作業後の一定時間（約10秒）の呼吸停止は困難で ある. 従って，本泪定では最大下及び最大作業に おいてもきわめて自然な状態で測定できる Filley $(1954)^{7)}$ の steady state method を探用した。 Linderholm (1957) ${ }^{18)}$ は肺毛細管血中の $\mathrm{CO}$ 零と仮定すると䄪10〜20\% CO 肺払散容量( D LCO) が低く見積られると報告し，補正式を考案した。 しかし，この方法でも動服血を採取しなければな らず，それには非常な困難がともなら。そこで， 
本測定では肺毛細管血の $\mathrm{CO}$ 分圧を零とみなし た。

今日, 臨床的に安静時のCO肺㹡散容量 $\left(\mathrm{D}_{\mathrm{LCO}}\right)$ の正常值を確立しつつあるが，泪定方法，測定器 具等の差異によって正常值にも幅があることが報 告されている. Single breath methodによる正常 人の安静時の $\mathrm{CO}$ 肺払散容量 $\left(\mathrm{D}_{\mathrm{LCO}}\right)$ の平均とし て, Forster $(1954)^{8)}$ は $24.9 \mathrm{ml} / \mathrm{min} / \mathrm{mmHg}$, Marks (1957) ${ }^{21)}$ は $19.5 \mathrm{ml} / \mathrm{min} / \mathrm{mmHg}$ を, 日本 人について金上，桂 $(1965)^{15)}$ は $30.2 \mathrm{ml} / \mathrm{min} / \mathrm{mm}$ $\mathrm{Hg}$ という值を報告している. Steady state method では Filley $(1954)^{7)} 16.9 \mathrm{ml} / \mathrm{min} / \mathrm{mmHg}$, Bates (1955) は $17.6 \mathrm{ml} / \mathrm{min} / \mathrm{mmHg}$, Marks $(1957)^{21)} 19.5 \mathrm{ml} / \mathrm{min} / \mathrm{mmHg}$ という值を報告し ている. 一般に， single breath D LCo よりも steady state D LCO が低い值を示すことが認めら れている. 本測定での一般成人男子の $\mathrm{CO}$ 肺拡散 容量 $\left(\mathrm{D}_{\mathrm{LCO}}\right)$ の $18.4 \mathrm{ml} / \mathrm{min} / \mathrm{mmHg}\left(\mathrm{D}_{\mathrm{LO}_{2}}: 22.3\right)$ は後者の steady state method の値とほぼ一致し た。

また，中・長距離選手の安静時の CO 肺拡散容 量( $\left.\mathrm{D}_{\text {LCO }}\right)$ は $26.7 \mathrm{ml} / \mathrm{min} / \mathrm{mmHg}\left(\mathrm{DLO}_{2}: 32.4\right)$ を示し，一般成人と $\mathrm{p}<0.05$ で有意な差を示さな かった。これは Magel (1969) ${ }^{21)}$ の水泳選手と非 選手との間に $\mathrm{p}<0.05$ で有意差を認めた報告と異 なった。しかし, Neuman (1962) ${ }^{23)}$, Bannister $(1960)^{3)}$ らの長距離選手と非選手の安静時の CO 肺拡散容量（D LCO）に有意差を認めなかった報告 と一致した。

作業中の酸素掑取量 $\left(\dot{\mathrm{V}} \mathrm{O}_{2}\right)$ と $\mathrm{CO}$ 肺拡散容量 （D LCo）との関係について, 諸外国では多くの研 究者によって報告されている. Holmgren (1964 $\left.{ }^{11)}, 1965\right)^{10)}$ は定常法で CO 肺拡散容量 ( D LCO) を測定し，心拍数の $120 / \min \left(40 \%\right.$ of $\max \dot{V}_{o_{2}}$ ) まで直線的に上昇するが，その後，酸素摄取量 $\left(\dot{V}_{O_{2}}\right)$ の增加にもかかわらず一定であることを 報告している. しかし，多くの研究者たち，Linderholm (1959) ${ }^{19)}$, Bannister $(1960)^{3)}$, Johnson $(1962)^{13)}$, Shepard $(1958)^{29)}$, Pirnay (1969'5), Magel $(1965)^{20)}$, Newman $(1962)^{23)}$, Cotes (19 $60)^{6)}$ らは酸素椇取量 $\left(\dot{\mathrm{V}} \mathrm{O}_{2}\right)$ と $\mathrm{CO}$ 肺拡散容量 （D LCO）が比例関係にあることを報告している.
我が国では，金上（1962） ${ }^{14)}$ らがわずか臨床的見 地から軽作業にともな5 CO 肺抎散容量 ( $\mathrm{D}_{\mathrm{LCO}}$ ) の変動をみてきたにすぎない，本測定において， 諸外国の多くの報告と同じよ5に雨グループと も，酸素掑取量 $\left(\mathrm{V}_{2}\right)$ と $\mathrm{O}_{2}$ および $\mathrm{CO}$ 肺拡散 容量（DLO2 および DLCo）は比例関係にあること が明らかとなった（図1，困 2 ）。一般成人の相 関係数は $\mathrm{r}=0.724$ となり, その四帰直線は $\hat{Y}=8$. $83 \mathrm{X}+17.94$ となった．また，中・長距離選手の相 関係数は $\mathrm{r}=0.828$ となり, その回帰直楾は $\hat{\mathrm{Y}}=$ $8.32 \mathrm{X}+26.31$ であった。これによると，中・長距離 選手と一般成人では同一量の酸素を摄取する時， 軽作業から最大作業まで前者の CO 肺拡散容量 （D LCO）が高いことを認めた。この結果は Bannister $(1960)^{3)}$, Mostyn (1963) ${ }^{22)}$ Gee (1965) ${ }^{9)}$ Holmgren $\left(1964,{ }^{11)} 1965\right)^{10)}$ らの報告と同じであ った。

この原因に関して, Cotes $(1968)^{6)}$ らは年令別 の CO 肺拡散容量（DLCO）を泪定し，その差異 が身体の大きさからくる肺胞昖散面積の差異であ ると述べている．Bates(1955)4), Ogilivie (1957) 24) らは CO 肺拡散容量 (D DCo) が横卧位では坐 位に比べて15～20\%増加することから，肺毛細血 管床の增加と肺抎散面積の拡大によるものであろ 5 と述へている. Holmgren(1965) ${ }^{10)}$ は年少女子 の CO 肺拡散容量（D $\mathrm{D}_{\mathrm{LCO}}$ ）は年少男子よりも少 ない。この違いは身体の大きさの差異によるより も大きいと報告している. Magel(1969) ${ }^{20)}$ はCO 肺拡散容量（DLCO）に肺容積（TLC）を考虑した KLCo でも水泳選手が一般成人よりも高いことか ら，肺拡散面積だけでなく，肺胞膜の性質，肺胞 毛細管血量 $(\mathrm{Vc})$ 等に原因していると推察してい るが，決定的な原因は究明されていない。

Magel (1969) ${ }^{20)}$ は水泳選手と非選手との最大 CO 肺拡散容量 (max D LCO) がそれぞれ安静值の 51\%および35\%增加したことを報告している，本 測定での中・長距離選手と一般成人の最大 $\mathrm{CO}$ 肺 拡散容量（max $\mathrm{D}_{\mathrm{LCO}}$ ）の增加はそれぞれ $85 \%$ お よで 102\%であった．その結果，增加率では Magel (1969) ${ }^{21)}$ の報出よりも高いことを認めたが， 一般成人は中・長距離選手よりも大きく， Magel $(1969)^{20)}$ の報告とは異なった結果となった。本 
測定における両グループの CO肺払散容量 $\left(D_{L}\right.$ LO $)$ の增加率の差は中・長距離選手 J. T., S. S. の安静 時の CO 肺払散容量 ( $\mathrm{D}_{\mathrm{LCO}}$ ) が高く, 增加率が 15〜20\%しか高くならなかったことに原因してい ると思われる。

Bannister $(1960)^{3)}$, Newman (1962) 23) Бは安 静時の CO 肺拡散容量(D D CO) $55 \%$ 水準で有意 な差を認めなかったが，最大 $\mathrm{CO}$ 肺拡散容量（max $\mathrm{D}_{\mathrm{LCO}}$ ）では $1 \%$ 水準で有意差を認めている．本测 定においては $5 \%$ 水準で有意差を認めた。

全身持久性の指標として最大酸素摄取量（max $\left.\dot{V} \mathrm{o}_{2}\right)$ が用いられているが，それと同様に CO お よび $\mathrm{O}_{2}$ 肺拡散容量 ( $\mathrm{D}_{\mathrm{LCO}}$ および $\mathrm{D}_{\mathrm{LO}}$ ) も全身 持久性の一分野である呼吸循環系の活動水準の指 標として重要である.

草野 ${ }^{17)}$ は男女24名の最大酸素摄取量 $\left(\max \mathrm{V}_{2}\right)$ とその時の CO 肺挔散容量 $\left(\mathrm{D}_{\mathrm{LCO}}\right)$ では相関係数 $\mathrm{r}=0.82, \mathrm{p}<0.001$ で有意な相関があることを認め ている. しかし，酸素摄取量 $\left(\dot{\mathrm{V}} \mathrm{O}_{2}\right)$ と CO 肺払 散容量（D LCO）が直線関係にならないことから， 最大酸素摄取量 ( $\max \dot{\mathrm{V}}_{\mathrm{O}_{2}}$ ) の時柿ならずしも最 大 $\mathrm{CO}$ 肺拡散容量 $\left(\max \mathrm{D}_{\mathrm{LCO}}\right.$ ) ではないと報告し ている. 本測定では酸素摄取量 $\left(\dot{\mathrm{V}} \mathrm{O}_{2}\right)$ と $\mathrm{CO}$ お よび $\mathrm{O}_{2}$ 肺拡散容量 (DLCO お。び $\left.\mathrm{DLO}_{2}\right)$ が直 線関係にあることから，最大酸素摄取量（max $\dot{\mathrm{V}} \mathrm{O}_{2}$ ) の時 $\mathrm{CO}$ および $\mathrm{O}_{2}$ 肺拡散容量 ( $\mathrm{D}_{\text {LCO }}$ お よび $\mathrm{D}_{\mathrm{LO}_{2}}$ ) 子最大と考光られる。そこで，中・長 距離選手15名，一般成人18名の計33名について, 最大酸素摄取量 $\left(\max \dot{\mathrm{V}} \mathrm{o}_{2}\right)$ と最大 $\mathrm{O}_{2}$ 肺拡散容量 (max $\mathrm{D}_{\mathrm{LO}_{2}}$ ) の関係をみた。 その結果, 相関係数 は $\mathrm{r}=0.817$ となり， $\mathrm{p}\langle 0.001$ で有意な相関を認め た(図 4).すなわち，最大酸素摄取量 $\left(\max \dot{\mathrm{V}} \mathrm{o}_{2}\right)$ の大きい者は最大 $\mathrm{O}_{2}$ 肺拡散容量 $\left(\max \mathrm{D}_{\mathrm{LO}}\right)$ む 大きいことが明らかとなった．諸外国での測定方 法は single breath method が多く, all-out 直後 の測定が困難なためにこの種の 報告はほとんど見 当らない。

酸素摂取量（ $\left.\dot{V}_{\mathrm{O}_{2}}\right)$ が大きくなるための要因は Bohr の式

$$
\dot{\mathrm{V}}_{2}=\mathrm{D}_{\mathrm{LO}_{2}}\left(\mathrm{P}_{\mathrm{AO}_{2}}-\mathrm{P}_{\overline{\mathrm{CO}}}\right)
$$

から推察できるそそれは(1) D $\mathrm{DL}_{2}$ を大きくするこ と(2) $\mathrm{P}_{\mathrm{AO}_{2}}-\mathrm{PCO}_{2}$ の勾配を大きくすることであ
る. 後者について, 即ち, $\mathrm{P}_{\mathrm{AO}_{2}}-\mathrm{P}_{\overline{\mathrm{CO}} 2}$ の勾配を 大きくするためには $\mathrm{P}_{\mathrm{AO} 2}$ (肺胞 $\mathrm{O}_{2}$ 分压) を大き くし， $\mathrm{P}_{\overline{\mathrm{CO}} 2}$ (肺胞毛細管血 $\mathrm{O}_{2}$ 分代) を小さくす ることが必要である. 肺胞における酸素分圧 $(\mathrm{P}$ $\mathrm{AO}_{2}$ ) は換気の增大によって高まり, all-out 近く では中・長距離選手，一般成人の区別なくほぼ同 じだと考劣れらる（四3），従って， $\mathrm{P}_{\overline{\mathrm{CO}} 2}$ を低く することが必要となってくる． $\mathrm{P}^{2} \mathrm{C}_{2}$ は末梢にお ける酸素消費量と心拍出量（文）の大小によって 決定される. 図3で認められるよ5に all-out 近 くでは約 $60 \mathrm{mmHg}$ で，両グループの間にはほと んど差が認められない。しかし，中・長距離選手 は一般成人よりる all-out 近くでは心拍出量 (文) が大きいと考克られるので，実際に活動筋に送ら れた酸素量は中・長距離選手の方が大きいものと 推察される. 従って, $\mathrm{P}_{\mathrm{AO}_{2}}-\mathrm{P}_{\overline{\mathrm{CO}}} 2$ の勾配の大小 よりむしろ $\mathrm{O}_{2}$ 肺拡散容量 $\left(\mathrm{D}_{\mathrm{LO}}\right)$ とよるところ の大小によって最大酸素掑取量 $\left(\max \dot{\mathrm{V}} \mathrm{o}_{2}\right)$ は決 定されるものと思われる.

Rosenberg(1967), ${ }^{28)}$ Reddan (1963), ${ }^{26)}$ Reuschlein(1968)27) らはトレーニングによって CO 肺 拡散容量 ( $\left.\mathrm{D}_{\mathrm{LCO}}\right)$ が增加することを埌告してい る. Newman (1962) ${ }^{28)}$ はトレーニング後の一定 作業における 酸素摄取量 $\left(\mathrm{V}_{2}\right)$ は低下するが, $\mathrm{CO}$ 肺拡散容量 ( $\mathrm{D}_{\mathrm{LCO}}$ ) は変化しなかったことを 報告している. 本測定に和ける両グループの CO 肺拡散容量 $\left(\mathrm{D}_{\mathrm{LCO}}\right)$ ，および最大 $\mathrm{CO}$ および $\mathrm{O}_{2}$ 肺払散容量 ( $\max D_{\text {LCo }}$ および $\max \mathrm{D}_{\mathrm{LO}}$ ) の差 異がトレーニングによるものかどらかについては 明らかでない。

$\mathrm{CO}$ および $\mathrm{O}_{2}$ 肺拡散容量 ( $\mathrm{D}_{\text {LCO }}$ および $\mathrm{D}_{\text {LO }}$ 2) は肺レベルと血液レベルの総合された能力であ る. 即ち, 前者では(1)肺胞換気量 $\left(\dot{\mathrm{V}}_{\mathrm{A}}\right)(2)$ 肺胞 $\mathrm{O}_{2}$ 分圧 $\left(\mathrm{P}_{\mathrm{AO}_{2}}\right)$ (3)肺胞拡散面積, (4)肺胞膜の透過性, 後者では (1) 肺胞毛細管血量 $(\mathrm{Vc})(2) \mathrm{Hb}$ 量等が考 えられる. 今後, これらの因子が $\mathrm{CO}$ および $\mathrm{O}_{2}$ 肺拡散容量 (DLCO および $\mathrm{D}_{\mathrm{LO}}$ ) にどのよ5な影 響を与えているかを明らかにすることによって， 中・長距離選手と一般成人の差異, トレーニング による変化がさらに 究明されなければならないだ ろ5。 


\section{要 約}

一般成人 (10名), 中・長距離選手 (6 名)、に ついて, Filley の steady, state method で CO 及び $\mathrm{O}_{2}$ 肺拡散容量 $\left(\mathrm{D}_{\mathrm{LCO}}\right.$ 及び $\mathrm{D}_{\mathrm{LO}_{2}}$ ), 肺胞 $\mathrm{O}_{2}$ 分圧 $\left(\mathrm{P}_{\mathrm{AO}_{2}}\right)$, 肺胞毛細血管 $\mathrm{O}_{2}$ 分圧 $\left(\mathrm{PcO}_{2}\right)$ 等を, Douglas bag method で酸素摄取量 $\left(\dot{\mathrm{V}}_{\mathrm{O}_{2}}\right)$ を测 定した。ささらに，一般成人（18名），中・長距離 選手 (15名) の計33名について，同じ測定法で最 大 $\mathrm{O}_{2}$ 肺拡散容量 (max $\left.\mathrm{DLO}_{2}\right)$ と最大酸素提取 量 $\left(\max \dot{\mathrm{V}} \mathrm{O}_{2}\right)$ を測定した。

（1）安静時の $\mathrm{O}_{2}$ 肺拡散容量 $\left(\mathrm{D}_{\mathrm{LO}}\right)$ は一般成人 が $22.3 \mathrm{ml} / \mathrm{min} / \mathrm{mmHg}$, 中・長距離選泘が 32.4 $\mathrm{ml} / \mathrm{min} / \mathrm{mmHg}$ となり，両グループの間に 5 \%水準で有意差を慧めなかった。

（2）一般成人と中・長距離選手の $\mathrm{O}_{2}$ 肺拡散容量 $\left(\mathrm{DLO}_{2}\right)$ は酸素摄取量 $\left(\mathrm{VO}_{2}\right)$ の増加とともに比 例して增加することを認めた。その回帰直線は 一般成人で

$$
\hat{\mathrm{Y}}=8.83 \mathrm{X}+22.07
$$

中・長距離選手は

$$
\hat{\mathrm{Y}}=8.32 \mathrm{X}+32.36
$$

であったそその結果，安静時から最大作業時ま で同一量の酸素を摄取するとき，中・長距離選 手は一般成人ょりも $\mathrm{O}_{2}$ 肺拡散容量 $\left(\mathrm{D}_{\mathrm{LO}}\right)$ が 大きいことが明らかとなった。

(3) 最大酸素摂取量 $\left(\max \mathrm{V}_{\mathrm{O}_{2}}\right)$ と最大 $\mathrm{O}_{2}$ 肺搪 散容量（max $\mathrm{D}_{\mathrm{LO}}$ ） との間には相関係数が $\mathrm{r}=$ 0.817 となり, 最大酸素掑取量 $\left(\max \dot{\mathrm{V}}_{2}\right)$ が 大きい者は最大 $\mathrm{O}_{2}$ 肺拡散容量 $\left(\max \mathrm{D}_{\mathrm{LO}_{2}}\right)$ \& 大きいことが明らかとなった。

(4) これらの結果，運動によって $\mathrm{O}_{2}$ 肺搪散容量 $\left(\mathrm{DLO}_{2}\right)$ が有酸素的作業能力の 寄与因子の一つ として增加するものと思われる。

本研究は文部省科学研究貫特定研究「生物圈の動態」 の一部として行われたあのである.

\section{引用文献}

1) Andersen, K. L.: Physiological working capacity. Health and Fitness in the World. p. 365367. The Athletic institute. 1961.

2) Anderson, T. W., and R. J. Shephard : The effects of hyperventilation and exercise upon the pulmonary diffusing capacity. Respiration, 25 : 465-484, 1968.

3) Bannister, R. G., J. E. Cotes, R. S. Jones and F. Meade: Pulmonary diffusing capacity on exercise in athletes and non-athletic subjects. J. Physiol., 152 : 66-67, 1960.

4) Bates, D. V., N. G. Boucot and A. E. Dormer : The pulmonary diffusing capacity in normal subjects J. Physiol., 129 : 237-252, 1955.

5) Bohr, C. : Über die spezifische Tätigkeit der Lungen bei der respiratorischen Gasaufnahme und ihr verhalten zu der durch die Alveolarwand stattfinden der Gasdiffusion. Scand. Arch. Physiol., 22 : 221-280, 1909.

6) Cotes, J. E., D. P. Snidal and R. H. Shepard : Effect of negative intr-alveolar pressure on pulmonary diffusing capacity. J. Appl. Physiol., 15: 372-376, 1960.

7) Filley, G. F., D. J. Maclntosh, and G. W. Wright : Carbon monoxide uptake and pulmonary diffusing capacity in normal subjects at rest and during exercise. J. Clin. Invest., $33: 530-5$ 39, 1954.

8) Forster, R. E., F. J. W. Roughton, L. Candar, E. A. Briscoe and F. Kreuzer : Apparent pulmonary diffusing capacity for $\mathrm{CO}$ at varying alveolar $\mathrm{O}_{2}$ tensions. J. Appl. Physiol., $11: 227-2$ 89, 1954.

9) Gee, J. B. L., L. G. Bentiroglio and E. Mostyn : Diffusion as a limiting factor in oxygen transport across the lung. p. 1-15. Proc. Int. Symp. Cardiovasc. Respir. Effects Hypoxia, ed. by Hatcher, Basel, Switzerland. 1965.

10) Holmgren, A. : On the variation of DLCO with increasing oxygen uptake during exercise in healthy trained young men and women. Acta physiol. Scand. 65 : 207-220, 1965.

11) Holmgren, A. : On the reproducibility of steady state DLCO measurements during exercise. Scand. J. Clin. Lab. Invest., 16 : 56-66, 1964.

12) Holmgren, A. : Cardiorespiratory determinants of cardiovascular fitness. Canad. Med. Ass. J., 96:697-702, 1967.

13) Johnson, Jr. R. L., H. F. Taylor and W. H. 
Lawson, Jr. : Maximal diffusing capacity of the lung for carbon monoxide. J. Clin. Invest., 44 : 349-355. 1965.

14）金上明夫，馬埸隹児，桂敏榯，白石光一郎，尾形 和夫，田中元亩，抑原事男：遇動負荷中の一酸化炭 美肺搪散能力涀定の臨床的意義について, 肺と心, 9 :140-153, 1962 .

15）金上晴夫，桂敏徼，白石光一郎，馬均健治，沼沼 夏治 : Single breath method 江よる健康者の一酸化 炭素拡散能力の測定について, 呼吸と循環 8:387-39 1,1965 .

16) Krogh, M. : Diffusion of gases through the lungs of man. J. Physiol., 49: 271-300, 1915.

17）草野腾：肺㹡散容量からみた全身持久性の研究. 東京大学教育学研究科体育学専攻課程修士 論文（19 69)

18) Linderholm, H. : On the significance of $\mathrm{CO}$ tension in pulmonary capillary blood for determination of pulmonary diffusing capacity with the steady state CO method. Acta Med. Scand., 156 : 413-427, 1957.

19) Linderholm, H. : Diffusing capacity of the lungs as a limiting factor for physical working capacity. Acta Med. Scand., 163 : 61-84, 1959.

20) Magel, J. R. and K. L. Andersen : Pulmonary diffusing capacity and cardiac output in young trained Norwegian swimmers and untrained subjects. Med. Sci. in Sports, 11:131-139, 1969.

21) Marks, A., D. W. Cugell, J.B. Cadigan, and E. A. Gaensler, : Clinical determination of the diffusion capacity of the lungs; comparison of methods in normal subjects and patients with alveolar-capillary blouk syndrome. Am. J. Med., 22 : 51-73, 1957.

22) Mostyn, E. M., S. Helle, J. B. L. Gee, L. G.
Bentivoglio and D. V. Bates: Pulmonary diffuing capacity of athletes. J. Appl. Physiol., 18 : 687-695, 1963.

23) Newman, F., B. F. Smalley and M. L. Thomson : Effect of exercise, body and lung size on $\mathrm{CO}$ diffusion in athletes and non-athletes.

J. Appl. Physiol., 17 : 649-655, 1962.

24) Ogilvie, C. M., R. E. Forster, W. S. Blakemore and J. W. Morton : A standardized breath holding technique for the clinical measurement of the diffusing capacity of the lung for carbon monoxide. J. Clin. Invest., $36: 1-17,19$ 57.

25) Pirnay, F., A. Fassotte, J. Gazon, R. Deroanne et J. M. Petit : Diffusion pulmonaire au coure de l'exercice musculaire. Int. $Z$. angew. Physiol., 28 : 31-37, 1969.

26) Reddan, W., F. Bongiorno, J. Burpee, P. Reuschlein, J. B. L. Gee and J. Rankin : Pulmonary function in endurance athletes. Fed. Proc., 22 : 396, 1963.

27) Reuschlein, P. S., W. G. Reddan, J. Burpee, J. B. L. Gee and J. Rankin : Effect of physical training on the pulmonary diffusing capacity during submaximal work. J. Appl.Physiol., 24 : 152-158, 1968.

28) Rosenberg, E. : Effect of physical training on the pulmonary diffusing capacity measured at rest. Int. Z. angew. Physiol., 24:246-253, 1967.

29) Shepard, R. H., E. Varnauskas, H. B. Martin, H.A. White, S. Permutt, J. E. Cotes and R. L. Riley: Relationship between cardiac output and apparent diffusing capacity in the lungs of normal men during treadmill exercise. J. Appl. Physiol. 12:205-210, 1958. 